range 20-100 mm. $\mathrm{Hg}$ and $\mathrm{Po}_{2}$ with an accuracy of + or $-5 \mathrm{~mm} . \mathrm{Hg}$ in the range $0-200 \mathrm{~mm}$. $\mathrm{Hg}$. If the operator is less skilled and uses only gas calibration, the range of uncertainty doubles. The assessment was carried out over the range 0-200 mm. Hg for $\mathrm{PO}_{2}$ and $20-100 \mathrm{~mm}$. Hg for $\mathrm{PCO}_{2}$.

We wish to thank Professor K. W. Donald for advice and encouragement, Mr. W. Lutz for statistical advice, and Mr. J. A. Ramsay and Mrs. F. Burgess for skilled technical assistance. The tonometer was provided by the John Risk Bequest of Edinburgh University.
REFERENCES

Bailey, N. T. J. (1959). Statistical Methods in Biology. London. Bishop, J. M., Pincock, A. C., Hollyhock, A., Raine, J., and Cole, R. B. (1967). Respir. Physiol., 1, 225.

Clark, L. C. (1956). Trans. Amer. Soc. artif. intern. Organs, 2, 41

Flenley, D. C. (1964). Quart. F. exp. Physiol., 49, 466.

and Millar, J. S. (1967). In preparation.

Moran, F., Kettel, L. J., and Cugell, D. W. (1966). F. appl. Physiol. 21, 725 .

Nunn, J. F. (1964). Brit. 7. Anaesth., 36, 327.

Severinghaus, J. W. (1962). Acta anaesth. scand., Suppl. No. 11 p. 207 and Bradley, A. F. (1958). 7. appl. Physiol., 13, 515.

\title{
Liquor Bilirubin Levels in Normal Pregnancy: A Basis for Accurate Prediction of Haemolytic Disease
}

\author{
E. D. MORRIS,* F.R.C.S., M.R.C.o.G.; JOHN MURRAY, † M.D., F.R.C.o.G., F.C.PATH. \\ C. R. J. RUTHVEN, $\ddagger$ M.SC., PH.D., F.R.I.C.
}

Brit. med.F., 1967, 2, 352-354

Amniocentesis has enjoyed ever-increasing popularity since Bevis (1956) related the absorption of the spectrophotometric curve at $450 \mathrm{~m} \mu$ with the prognosis of haemolytic disease of the newborn. In many countries estimation of liquor pigment levels has been preferred to maternal antibody titres as a guide for induction of labour (Walker, 1957 ; Cary, 1960 ; Freda, 1964); however, the general experience has been that the bile pigment level alone can be most misleading (Liley, 1963), particularly when specimens are contaminated with blood.

A number of wrong predictions were made at Queen Charlotte's Hospital in 1965 ; these included five Rh-negative babies which had been predicted as affected Rh-positive. At that time the only information available on the "normal" pigment level in liquor amnii was from $\mathrm{Rh}$-negative women with isoantibodies other than $\mathrm{Rh}$ who gave birth to normal babies or from $\mathrm{Rh}$-isoimmunized women who gave birth to Rh-negative babies (Walker and Jennison, 1962 ; Walker et al., 1964 ; Watson et al., 1965).

Estimation was therefore made of pigment levels in liquor amnii in a series of normal Rh-positive pregnant women.

\section{Patients and Methods}

Liquor specimens from $29 \mathrm{Rh}$-positive normal pregnant women were examined during the 30 th to 32 nd weeks of gestation. These patients were all volunteers who were informed that the test was required purely for research purposes and was not part of their prenatal treatment. Specimens of liquor amnii were also taken from $22 \mathrm{Rh}$-negative mothers with histories of severe haemolytic disease and heterozygous husbands, or rising $\mathrm{Rh}$-antiglobulin antibody titre, or with an antibody titre that conflicted with a history of previous offspring with haemolytic disease or of stillbirths. In less severe cases the specimens were taken during the 28 th and 30th weeks of gestation, but in more severe cases likely to require intrauterine transfusion tests were made as early as the 20 th week.

About $10 \mathrm{ml}$. of liquor amnii was obtained by abdominal paracentesis, as described by Walker and Jennison (1962). The specimen was centrifuged, first in a clinical centrifuge to remove

\footnotetext{
* Resident Obstetrician.

+ Director of Pathology.

‡ Senior Biochemist.

Queen Charlotte's Maternity Hospital and Institute of Obstetrics and Gynaecology, London W.6.
}

any red cells, and then the supernatant was recentrifuged at 17,000 r.p.m. $(35,000 \mathrm{~g})$ in a refrigerated $\left(4^{\circ}\right.$ C. $)$ centrifuge for 20 minutes to obtain a clear cell-free solution.

The optical extinction (E) of the clarified liquor was measured against water as a blank in a $1-\mathrm{cm}$. cuvette at $454,490,520$, and $574 \mathrm{~m} \mu$ with a Unicam S.P.500 spectrophotometer. The total bile pigment concentration in the specimen was determined by diazo-coupling, as described by Watson (1962), except that $1.4 \mathrm{ml}$. instead of $1 \mathrm{ml}$. liquor was taken for the test and the reagents were increased proportionally. The total protein concentration was determined by the biuret reaction: $0.5 \mathrm{ml}$. of liquor (or $0.25 \mathrm{ml}$. where the protein concentration was found to be greater than $5 \mathrm{mg} . / \mathrm{ml}$.), diluted to $1 \mathrm{ml}$. with $0.9 \% \mathrm{w} / \mathrm{v}$ saline, was mixed with $1 \mathrm{ml}$. of biuret reagent, prepared by diluting stock reagent (Weichselbaum, 1946) one in five with $0.2 \mathrm{~N}$ sodium hydroxide containing $0.5 \% \mathrm{w} / \mathrm{v}$ potassium iodide. The intensity of the colour developing after standing for 15 minutes at $37^{\circ} \mathrm{C}$. was measured spectrophotometrically at $540 \mathrm{~m} \mu$. The protein concentration in the specimen was calculated by comparison with standards prepared from vacuumdried bovine albumin "Armour" treated with biuret reagent under the conditions of the test.

Cord and infant serum bilirubin estimations were carried out by the method of Lathe and Ruthven (1958). Group, Rh type, Coombs and albumin tests, and haemoglobin determination were made on cord blood. Mothers' blood was grouped and Rh-typed, and the antibody titre was followed throughout pregnancy by means of the indirect Coombs test.

\section{Results}

The individual levels of protein concentration in liquor from $25 \mathrm{Rh}$-positive pregnancies, and bile pigment concentration in these cases, plus four similar ones, are shown in Table I, together with the observed differences in optical extinction $(\Delta \mathrm{E})$ between 454 and $574 \mathrm{~m} \mu$ and between 490 and $520 \mathrm{~m} \mu$, as described by Alvey (1964) and Knox et al. (1965) respectively. It should be emphasized that all optical readings were made in a cell of $1 \mathrm{~cm}$. light path, whereas Knox et al. (1965) used a light path of $0.5 \mathrm{~cm}$. Therefore our values of $\Delta \mathrm{E}(490-520 \mathrm{~m} \mu)$ are equivalent to twice those given by Knox et al. These results, apart from protein concentration, are summarized in Table II. They are classified in the respective ranges used for bilirubin 
by Watson (1962) and Watson et al. (1965), for $\Delta \mathrm{E}$ (454-574 $\mathrm{m} \mu$ ) by Alvey (1964), and for $\Delta \mathrm{E}(490-520 \mathrm{~m} \mu)$ related to the "liquor ratio" of Knox et al. (1965) and Savage et al. (1966).

TABLE I.-Analysis of Liquor Amnii from Rh-positive Normal Pregnancies. Total Bile Pigments, Differences in Optical Extinction $(\triangle E)$, and Protein Levels from 29 Cases

\begin{tabular}{|c|c|c|c|c|}
\hline Case & $\begin{array}{l}\text { Protein } \\
\text { (mg./ml.) }\end{array}$ & $\begin{array}{l}\text { Total Bile } \\
\text { Pigment } \\
(\mu \mathrm{g} . / \mathrm{ml} .)\end{array}$ & $\frac{\Delta \mathrm{E}}{(454-574 \mathrm{~m} \mu)}$ & $\begin{array}{c}\Delta \mathrm{E} \\
(490-520 \mathrm{~m} \mu)\end{array}$ \\
\hline $\begin{array}{r}\text { A } \\
\text { B } \\
\text { C } \\
\text { D } \\
1 \\
2 \\
3 \\
4 \\
5 \\
6 \\
7 \\
8 \\
9 \\
10 \\
11 \\
12 \\
13 \\
14 \\
15 \\
16 \\
17 \\
18 \\
19 \\
20 \\
21 \\
22 \\
23 \\
24 \\
25\end{array}$ & $\begin{array}{l}\text { 二 } \\
\bar{z} \\
3.54 \\
3.52 \\
3.50 \\
2.52 \\
4.60 \\
4.45 \\
3.32 \\
2.74 \\
5.56 \\
3.88 \\
4.25 \\
4.49 \\
3.65 \\
3.40 \\
2.70 \\
5.32 \\
3.12 \\
2.36 \\
4.50 \\
3.41 \\
3.30 \\
3.04 \\
3.21 \\
3.32 \\
5.87\end{array}$ & $\begin{array}{l}0.4 \\
1.5 \\
0.5 \\
3.4 \\
0.9 \\
0.9 \\
0.8 \\
0.7 \\
1.3 \\
0.8 \\
0.6 \\
0.7 \\
1.4 \\
0.9 \\
1.0 \\
1.1 \\
0.6 \\
0.7 \\
0.5 \\
1.0 \\
0.7 \\
0.5 \\
0.9 \\
0.9 \\
0.7 \\
0.6 \\
0.5 \\
0.8 \\
0.9\end{array}$ & $\begin{array}{l}0.053 \\
0.143 \\
0.043 \\
0.310 \\
0.070 \\
0.079 \\
0.070 \\
0.047 \\
0.111 \\
0.083 \\
0.073 \\
0.065 \\
0.122 \\
0.085 \\
0.120 \\
0.103 \\
0.055 \\
0.077 \\
0.054 \\
0.095 \\
0.104 \\
0.058 \\
0.097 \\
0.087 \\
0.076 \\
0.073 \\
0.068 \\
0.073 \\
0.097\end{array}$ & $\begin{array}{l}0.015 \\
0.058 \\
0.013 \\
0.135 \\
0.027 \\
0.032 \\
0.025 \\
0.018 \\
0.049 \\
0.033 \\
0.024 \\
0.017 \\
0.052 \\
0.028 \\
0.045 \\
0.044 \\
0.017 \\
0.027 \\
0.019 \\
0.037 \\
0.031 \\
0.021 \\
0.041 \\
0.032 \\
0.030 \\
0.029 \\
0.026 \\
0.028 \\
0.039\end{array}$ \\
\hline
\end{tabular}

$\Delta=$ Difference.

TABLE II.--Summary of Results from Analysis of Liquor Amnii from 29 Rh-positive Normal Pregnancies

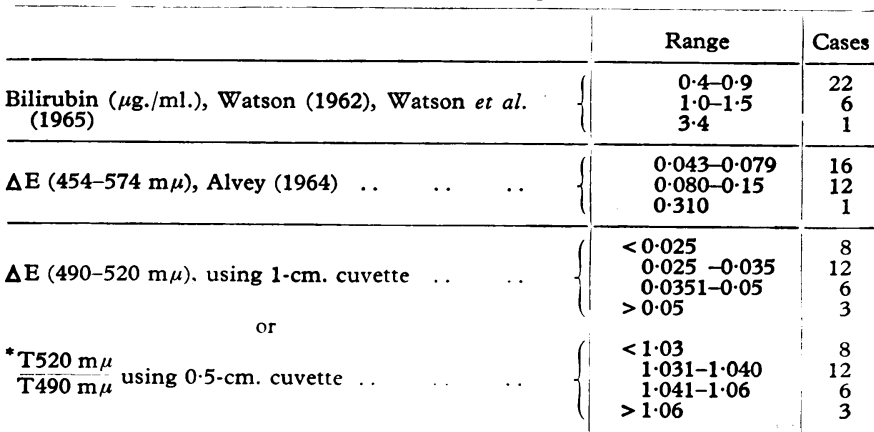

* Liquor ratio of Knox et al. (1965) and Savage et al. (1966), using 0.5-cm cuvette $\%$ Transmittance (T) at $520 \mathrm{~m} \mu$.

\% Transmittance (T) at $490 \mathrm{~m} \mu$ equivalent to $\left\{\frac{\mathrm{T} 490 \mathrm{~m} \mu}{\mathrm{T} 490}\right\}$ using $1-\mathrm{cm}$. cuvette.

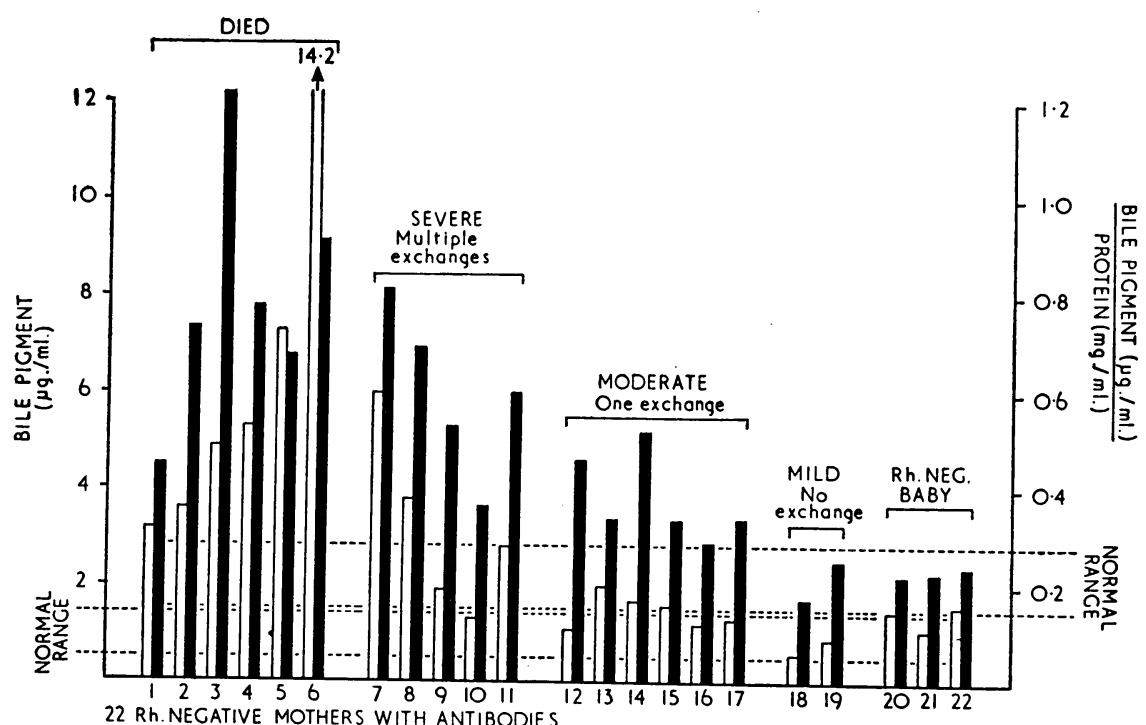

Results from $22 \mathrm{Rh}$-negative mothers with antibodies. Histograms comparing the variation in liquor bile pigment (open columns) with the ratio bile pigment/protein (solid columns), grouped according to the observed degree of severity of haemolvtic disease in the infant.
A summary, and evaluation of the calculated ratios of

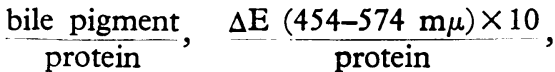

$$
\text { and } \frac{\Delta \mathrm{E}(490-520 \mathrm{~m} \mu) \times 10^{2}}{\text { protein }}
$$

are given in Table III. The mean and standard deviation of the single measurements-bilirubin, $\Delta \mathrm{E}(454-574 \mathrm{~m} \mu)$, and $\Delta \mathrm{E}(490-520 \mathrm{~m} \mu)$-is compared with the respective mean and standard deviation of these quantities after division by protein. Both the standard deviation of ratios and also actual ranges of ratios expressed as percentages of means were less than the corresponding figures for the individual values.

Some of the babies of the $\mathrm{Rh}$-positive mothers became appreciably jaundiced (serum bilirubin more than $10 \mathrm{mg} . / 100 \mathrm{ml}$.), though, with the exception of one case, none of these infants were from mothers with the higher liquor pigment level (more than $1 \mu \mathrm{g} . / \mathrm{ml}$.). In addition, there was no evidence that jaundice was due to any other cause than the inability to conjugate bilirubin owing to liver immaturity. All the cord bloods were negative to the Coombs and albumin tests and there was no suggestion of haemolytic disease due to $\mathrm{ABO}$ incompatibility.

The value of the pigment/protein ratio in prognosis is shown in the Chart, which gives the results of liquors from $22 \mathrm{Rh}$ negative isoimmunized women.

\section{Discussion}

Various workers have suggested devices for improving the information obtained from the spectral curve. Most of these methods have consisted in the subtraction of one optical density from another in order to cut out absorption due to haemoglobin and other pigments. The methods of Alvey (1964), Knox et al. (1965), and Savage et al. (1966) when used alone did not give as good predictions in the 29 normal liquors as did simple bilirubin estimations.

In a considerable number of cases an affected baby, often moderately and sometimes severely affected, would have been predicted if these specimens had been from $\mathrm{Rh}$-negative women with antibodies. With the Alvey (1964) method at least 12 babies should have been moderately or severely affected and one very severely. By application of the "liquor-ratio" method of Knox et al. (1965) and Savage et al. (1966) nine cases would have been classified as having at least moderate and in some cases severe or very severe haemolytic disease, whereas on simple bilirubin determination only six would have been more than mildly affected and only one severely (Table II).

Tests on the babies after birth showed no evidence of haemolytic disease. The babies were completely normal.

As an aid in the prediction of severity of haemolytic disease, others have made it amply clear from their results that liquor absorption characteristics or bile pigment levels could be used only in conjunction with other observations, such as the mother's antibody titre (particularly rising); number of pregnancies; and genotype, homozygous or heterozygous, of the husband. Our results obtained in this group of $\mathrm{Rh}$-positive women fully endorsed these warnings on the caution required in relying on predictions from analysis of liquor bile pigment alone.

The way bilirubin gets into the liquor is not known, and there are probably a number of factors that make liquor bilirubin concentration not always a true reflection of the bilirubin production in the foetus. However, 
one complicating factor of which we and others have been aware in the interpretation of results, all based on concentration, is the wide range of total liquor volume-that is, 500-1,500 ml.

If the liquor volume were known then probably a truer assessment of total bilirubin production would be obtained. What was required was a simple way to measure liquor volume.

Cherry et al. (1965) have shown that the protein concentration of the liquor is probably related to the total liquor volume, and they suggest using the ratio of bile pigment to protein,
(Cases 20, 21, and 22) giving birth to Rh-negative babies the ratios were of particular value, since all three mothers had histories of very severe haemolytic disease.

For guidance in treatment of isoimmunization between 30 and 34 weeks it would seem that a bilirubin $\mu \mathrm{g} . / \mathrm{ml}$. protein $\mathrm{mg} . / \mathrm{ml}$.

ratio

of less than 0.3 would not justify any interference with pregnancy. With ratios over 0.3 a degree of hacmolytic disease is likely, and with ratios as high as 0.5 severe disease may be

TABle III.-Mean Protein and Pigment Levels and Mean Pigment/Protein Ratios, together with S.D.s and Ranges Evaluated in 25 Normal Specimens of Liquor Amnii at 30 to 32 Weeks

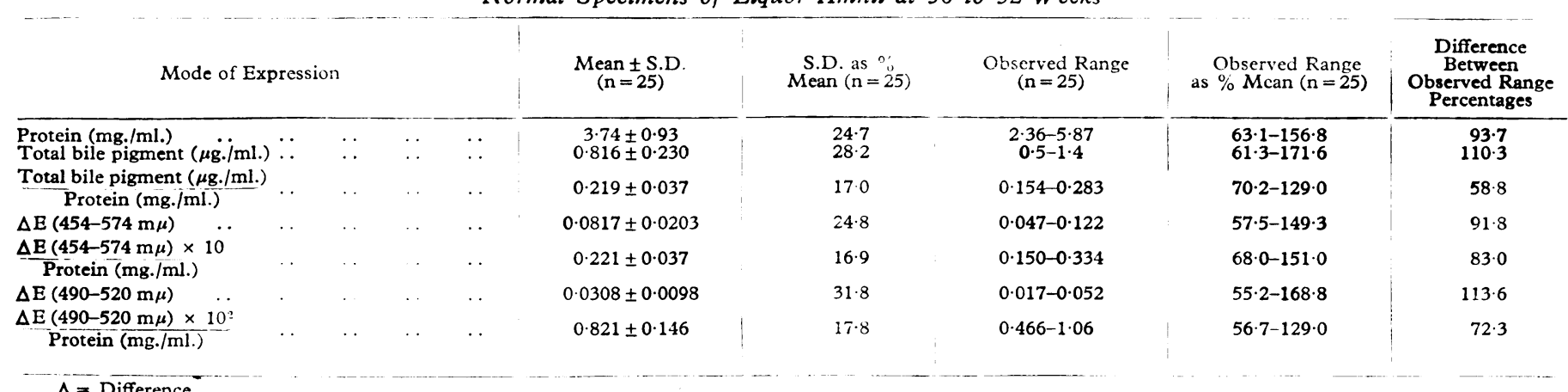

rather than the bile pigment concentration alone, as a measure of the severity of haemolytic disease in the foetus. By using the ratio as an index of the disease the clinically misleading drop in the concentration of liquor bile pigment towards term, due to increase in liquor volume, was compensated by an accompanying fall in liquor protein concentration.

Walker et al. (1964), Cherry et al. (1965), and Watson et al. (1965) have shown that increases in protein in amniotic fluid are associated with large increases in bile pigments. However, this effect is most marked in the most severe cases, which of ten leads to a stillbirth. In the less severe cases, the group which is most difficult to predict correctly, any correlation between protein level and severity is much less, and it is probable that in these circumstances the rate of protein excretion into the liquor is largely unconnected with haemolytic disease and that the protein concentration may be an approximate indirect indication of the liquor volume. Thus the ratio may not only be useful in eliminating the effect of volume changes in the concentration of liquor bile pigment in the same patient during gestation, as stressed by Cherry et al. (1965), but it may also be of value in reducing variation between patients having foetal haemolytic disease of similar severity but with different liquor volume.

We have therefore determined the protein concentration in 25 of the liquors from 29 normal subjects, and the ratios between bilirubin, $\Delta \mathrm{E}(454-574 \mathrm{~m} \mu)$, and $\Delta \mathrm{E}(490-520 \mathrm{~m} \mu)$ were calculated. In all three methods the value of the standard deviation of the ratio expressed as a percentage of its respective mean was less than the corresponding value for the undivided figure (Table III).

A comparison between bile pigment level and the ratio of bile pigment to protein in liquors taken from $22 \mathrm{Rh}$-negative mothers with antibodies is shown in the Chart. In general both bilirubin level and its ratio with protein did indicate the severity of haemolytic disease. However, in four cases-one severely (Case 10) and three moderately affected (Cases 12, 16, and 17)-the bile pigment level was in the normal range, while the ratio was above, thus giving a better prediction of outcome. In Case 9 the ratio value also provides a more accurate guide to the severity of haemolytic disease. In the three mothers expected. At 20 to 24 weeks a ratio of 0.4 or more would be an indication for intrauterine transfusion.

\section{Summary}

Liquor amnii from 29 normal Rh-positive subjects was examined in order to establish normal bile pigment levels. In 25 of these a pigment/protein ratio was calculated to avoid the effects of variations of liquor volume on pigment concentration.

Similar ratios from $22 \mathrm{Rh}$-negative women with antibodies gave a good indication of the severity of haemolytic disease.

It is concluded that deductions from any method of simple estimation of pigment concentration percentage may suggest grossly inaccurate prognoses because of variation in liquor volume, and that a pigment/protein ratio is a much more accurate guide.

At Queen Charlotte's Hospital the pigment-protein ratio is found particularly useful in helping to avoid interfering with rhesus-negative or mildly affected foetuses.

Requests for reprints should be sent to Dr. John Murray, Bernhard Baron Memorial Research Laboratories, Queen Charlotte's Maternity Hospital, London W.6.

\section{REFERENCES}

Alvey, J. P. (1964). Amer. F. Obstet. Gynec., 90, 769.

Bevis, D. C. A (1956). 7. Obstet. Gynaec. Brit. Emp., 63, 68

Bevis, D. C. A. (1956). F. Obstet. Gynaec.

Cherry, S. H., Kochwa, S., and Rosenfield, R. E. (1965). Obstet. and Gynec., 26, 826.

Freda, V. J. (1964). Abstracts of 10th Congress of the International Society of Haematology, 1, 26. Stockholm.

Knox, E. G., Fairweather, D. V. I., and Walker, W. (1965). Clin. Sci., 28,147 .

Lathe, G. H., and Ruthven, C. R. J. (1958). 7. clin. Path., 11, 155.

Liley, A. W. (1963). Amer. 7. Obstet. Gynec., 86, 485.

Savage, R. D., Walker, W., Fairweather, D. V. I., and Knox, E. G. (1966). Lancet, 2, 816.'

Walker, A. H. C. (1957). Brit. med. 7., 2, 376

Walker, A. H. C. (1957). Brit. med. 7., 2, 376.

Walker, W., Fairweather, D. V. I., and Jones, P. (1964). Ibid., 2, 141

Walker, W., Fairweather, D. V. I., and Jones, P. (1964)

Watson, D. (1962). Proc. Ass. clin. Biochem., 2, 81. Weichselbaum, T. E. (1946). Amer. F. clin. Path., 10, Tech. Sect., p. 40. 